\title{
Pemanfaatan Animatron untuk Pembuatan Iklan Animasi bagi Para Pelaku UMKM di Tangerang Selatan
}

\author{
Dian Pratiwi', Iwan Purwanto ${ }^{2}$, Ratna Shofiati ${ }^{3}$, Yunia Ningsih ${ }^{4}$, Muhammad \\ Azamy $^{5}$, Tasya Aulia ${ }^{6}$ \\ 1,2,3, 4, 5, 6Universitas Trisakti \\ e-mail: $\underline{1 \text { dian.pratiwi@trisakti.ac.id }}{ }^{2}{ }^{\text {iwan.purwanto@trisakti.ac.id, }}$ \\ 3ratna@trisakti.ac.id, \\ ${ }^{4}$ yunia@trisakti.ac.id, ${ }^{5}$ m.azamy064001800004@std.trisakti.ac.id, ${ }^{6}$ tasya065001800022@s \\ td.trisakti.ac.id
}

\begin{abstract}
Abstrak
Teknologi semakin berkembang pesat, menuntut adanya kebaharuan pula dalam metode promosi atau periklanan produk. Adanya pengetahuan dan keterampilan yang masih terbatas para pelaku UMKM mengenai hal tersebut, menjadikan kegiatan pelatihan untuk pembuatan iklan produk sangat perlu diterapkan guna membantu usaha mereka agar lebih dikenal dan mampu menarik pembeli dengan bentuk promosi yang lebih interaktif. Inilah yang kemudian tim Pengabdian pada Masyarakat dari Jurusan Teknik Informatika Universitas Trisakti lakukan, dengan mengajarkan cara membuat iklan produk berbentuk animasi dengan menggunakan perangkat lunak daring berupa Animatron. Dalam pelaksanaannya, pelatihan ini diikuti secara daring melalui Google Meet oleh 12 orang (6 panitia dan 6 peserta) terdiri dari 2 sesi, yaitu sesi pengenalan dasar Animatron dan sesi studi kasus pembuatan iklan promosi produk kopi. Berdasarkan hasil kuisioner awal saat pendaftaran, diketahui bahwa $100 \%$ peserta belum pernah menggunakan Animatron untuk membuat iklan dan sebanyak $66.7 \%$ peserta beriklan melalui media sosial Instagram. Dan dari hasil evaluasi pelaksanaan kegiatan, didapat umpan balik yaitu $60 \%$ peserta menyatakan mampu menerapkan Animatron secara mandiri dan pelatihan ini sangat berguna dalam mempromosikan usaha mereka nantinya. Dengan demikian dapat disimpulkan bahwa pelatihan pembuatan iklan produk berbasis animasi ini telah berhasil memberikan pengetahuan serta keterampilan para pelaku UMKM untuk membuat iklan produk dengan mudah dan lebih menarik dalam bentuk animasi.
\end{abstract}

Kata Kunci:Animatron, Kahoot, Iklan, Media Sosial, UMKM

\begin{abstract}
Technology that is growing rapidly, also demands novelty in the method of product promotion or advertising. The existence of limited knowledge and skills of MSME actors regarding this matter, makes training activities for making product advertisements very necessary to be implemented in order to help their businesses become better known and able to attract buyers with more interactive forms of promotion. This is what the Community Service team from the Department of Informatics, Trisakti University, did, by teaching them how to
\end{abstract}


create animated product advertisements using online software in the form of Animatron.In its implementation, this training was attended online through Google Meet by 12 people (6 committees and 6 participants) consisting of 2 sessions, namely a basic introduction to Animatron and a case study session on making coffee product promotional advertisements. Based on the results of the initial questionnaire during registration, it is known that $100 \%$ of participants have never used Animatron to create advertisements and as many as $66.7 \%$ of participants advertise through Instagram social media. And from the results of the evaluation of the implementation of the activity, feedback was obtained that $60 \%$ of participants stated that they were able to implement Animatron independently and this training was very useful in promoting their business later. Thus it can be concluded that this animation-based product ad creation training has succeeded in providing knowledge and skills of MSME actors to make product advertisements easier and more attractive in the form of animation.

Keywords:Animatron, Kahoot, Advertising, Social Media, MSME

\section{Pendahuluan}

Makin maraknya beberapa media promosi membuat persaingan penjualan produk semakin tinggi pula.Jenis media konvensional pun mulai ditinggalkan dan banyak beralih ke media teknologi seperti videotron atau layar-layar LCD.Bahkan saat ini, penjualan secara digital didominasi para pelaku Usaha Mikro Kecil Menengah (UMKM) dengan melalui social media, seperti Instagram, Facebook, Twitter, maupun Telegram.Penggunaan media tersebut tentunya perlu didukung dengan isi konten promosi yang menarik pula dalam mengiklankan produk, terutama produkproduk yang diperkenalkan oleh para UMKM.UMKM di Indonesia sering kali menghadapi berbagai masalah seperti promosi, pemasaran dan penjualan.Terutama saat kondisi pandemi sekarang ini, yang berimbas pada hampir segala sektor, tak terkecuali UMKM. Berdasarkan informasi dari CNN Indonesia (Hasibuan, 2020), di tahun 2020 UMKM yang mampu bertahan hanya sekitar 48\%. Kondisi tersebut menjadikan pelaku UMKM harus lebih kreatif dalam melakukan penjualan produknya agar bisa tetap terus bertahan menjalankan usahanya. Salah satu cara yang bisa dilakukan adalah dengan mempromosikan produknya melalui bentuk iklan maupun pesan melalui media sosial. Namun sayangnya, konten promosi dalam media sosial umumnya hanya terbatas berupa teks dan gambar.Masih sangat jarang promosi produk dalam suatu media sosial dilakukan dengan menyampaikannya dalam bentuk video, mengingat tidak semua pelaku UMKM mampu membuat video iklan yang menarik tentang produknya. Melihat hal tersebut, maka pelatihan pembuatan iklan produk sangat perlu dilakukan kepada para pelaku UMKM, dan inilah yang kemudian diterapkan oleh tim dari Jurusan Teknik Informatika, Universitas Trisakti.

Pada dasarnya, pelatihan yang sama mengenai pembuatan animasi sudah pernah dilakukan, baik oleh tim dari Universitas Trisakti maupun oleh tim dari institusi/universitas lainnya (Hadi, 2015). Pembekalan pembuatan animasi tersebut ada yang diberikan untuk masyarakat umum/LPK sebagai media iklan dan sosialisasi (Afgan, 2012), ada pula yang diperuntukkan khusus guru sebagai 
alternatif media pembelajaran (Indrawan et al., 2017; Wiyaka et al., 2017). Animasi yang diajarkan juga ada yang berbentuk 2D maupun 3D, dengan menerapkan aplikasi yang mudah juga untuk dipelajari oleh pemula atau orang awam sekalipun seperti Scratch dan Blender 3D (Permana et al., 2017; Zebua et al., 2020). Sedangkan kegiatan PKM yang pernah tim Universitas Trisakti lakukan mengenai animasi adalah berupa pelatihan pembuatan iklan dengan menggunakan aplikasi Animaker kepada para UMKM di wilayah Jakarta dan Tangerang Selatan (Pratiwi et al., 2021). Dari hasil kegiatan tersebut telah didapat umpan balik positif, dimana para peserta sangat antusias untuk dapat mengikuti kegiatan yang sama jika dilakukan kembali. Oleh karena itu, pelatihan ini kemudian tim adakan kembali dengan sasaran yang sama yaitu para pelaku UMKM di wilayah Tangerang Selatan, namun dengan menggunakan aplikasi animasi yang berbeda yaitu Animatron. Diharapkan nantinya dalam hasil kegiatan ini akan mampu memberikan pengetahuan cara penggunaan aplikasi Animatron kepada masyarakat, khususnya UMKM dalam mengembangkan iklan produk mereka dalam bentuk animasi, meningkatkan keterampilan dan kreativitas para pelaku UMKM dalam mempromosikan produk, serta juga sebagai bentuk penerapan salah satu Tridharma di Universitas Trisakti. Selain itu manfaat yang mungkin bisa diperoleh dari kegiatan juga para pelaku UMKM akan memperoleh pengetahuan dan keterampilan mengenai cara membuat iklan dalam bentuk animasi tanpa biaya/gratis, mengurangi pemakaian media iklan konvensional, sehingga dapat lebih menghemat pengeluaran para peserta UMKM, dan juga mengurangi kesulitan-kesulitan yang timbul dalam memasarkan produk UMKM.

\section{Metode}

Metode yang dilaksanakan dalam kegiatan ini dapat digambarkan melalui diagram alir berikut:

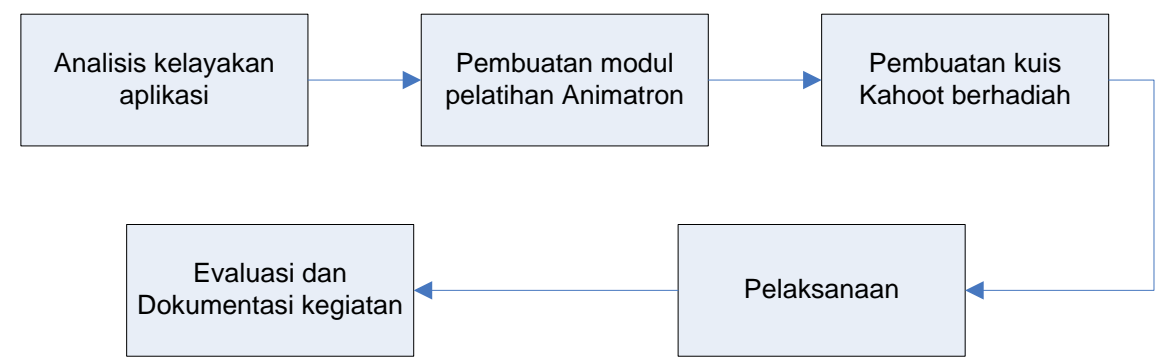

Gambar 1. Diagram alir metode pelaksanaan pelatihan

Dalam mencari solusi dari permasalahan yang ada, tim melakukan uji coba aplikasi daring yang dapat digunakan dengan mudah untuk para peserta PKM yang mayoritas belum pernah mengikuti pelatihan pembuatan iklan produk berbasis animasi. Aplikasi yang diuji coba oleh tim dimulai Animatron, Powtoon, hingga Animaker. Setelah mempelajari dan menguji hasil iklan yang dibuat, penggunaan tools online Animatron dipilih untuk media yang akan digunakan oleh peserta saat membuat iklan animasi. Hal ini dikarenakan tools Animaker sudah pernah diterapkan pada kegiatan PKM tahun sebelumnya, dan aplikasi Powtoon masih 
lebih sulit diimplementasikan dibandingkan dengan Animaker maupun Animatron (Narayanan, 2019), Kemudian, dalam memudahkan peserta mempelajari Animatron, tim menyediakan modul Animatron berbentuk file pdf yang dapat mereka langsung coba. Tim juga memberikan contoh pembuatan iklan mengenai ajakan membeli kopi produk dari Trisakti pada sesi pelatihan studi kasus, untuk memudahkan mereka dalam mencontoh luaran iklan pada penjualan produk mereka sendiri.

\section{Materi Kegiatan}

Kegiatan yang dilaksanakan oleh tim Dosen dan mahasiswa Jurusan Teknik Informatika ini memiliki 2 jenis materi yang disampaikan kepada para pesertanya, yaitu materi dasar Animasi dan Animatron, serta materi studi kasus untuk membuat iklan sederhana dalam bentuk animasi video.

Materi Animasi dan Animatron terdiri dari teori dasar animasi, pengenalan Animatron, keunggulan Animatron, menu-menu standar dalam lembar kerja Animatron dan penjelasan cara bagaimana membuat animasi yang menarik menggunakan Animatron. Sedangkan untuk materi studi kasus, para peserta akan secara daring diajarkan step-by-step untuk membuat animasi iklan promosi produk kopi Trisakti. Selain dari kedua materi utama tersebut, kegiatan ini juga diberikan kuis berhadiah dengan memberikan 5 buah pertanyaan melalui sarana pembelajaran sekaligus permainan secara online yaitu Kahoot.

Iklan sendiri merupakan sebuah bentuk komunikasi, yang dapat disampaikan melalui berbagai cara seperti melalui televisi, media cetak, radio, internet, dan lainlain (Cook, 2019). Iklan memiliki peranan penting dari suatu perusahaan, guna mempromosikan produk-produk kepada khalayak.Seiring berkembangnya teknologi, bentuk iklan juga mengalami perubahan.Dari yang sebelumnya berisi video pendek dengan aktor/aktris di dalamnya, kini peran tersebut sudah dapat digantikan dengan teknologi animasi.Hal tersebut tentunya menguntungkan bagi pengguna iklan karena dapat mengurangi biaya dalam pembuatan iklan serta waktu yang dibutuhkan.Dan peluang ini tentu banyak dimanfaatkan oleh para produsen iklan, untuk berlomba-lomba membuat animasi iklan yang menarik dengan harga yang terjangkau.

Animasi sendiri sudah diperkenalkan sebagai salah satu penerapan bentuk iklan yang menarik dari sejak tahun 1928, dalam suatu acara siaran televisi berjudul 'Steamboat Willie' (Cook, 2019), yang kemudian diikuti munculnya tokoh Mickey di tahun 1932 sebagai tokoh animasi untuk promosi produk merchandise Hollywood. Dalam membuat iklan animasi, dipilih Animatron sebagai media aplikasi yang akan diterapkan dalam pelatihan ini. Animatron sendiri merupakan aplikasi pembuatan video yang dapat diakses secara online dengan mudah dan sangat canggih, dimana Animatron menyediakan berbagai menu kepada pengguna untuk dapat membuat animasi maupun video secara langsung hanya melalui browser (Melet, 2011). Aplikasi ini dibangun dengan platform HTML5 sehingga video animasi yang dihasilkan dapat dilihat di berbagai jenis browser dan media.Url yang dapat diakses yaitu https://www.animatron.com/. 


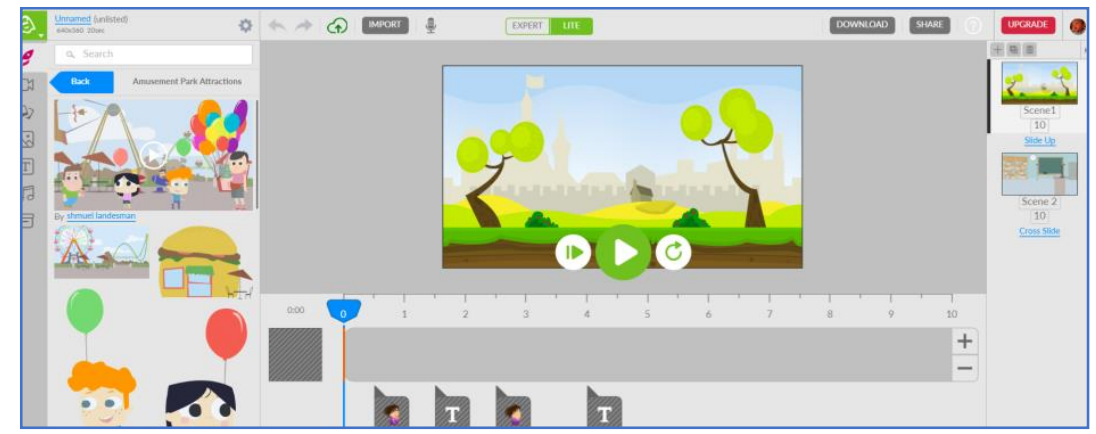

Gambar 2. Lembar Kerja Animatron

Untuk memeriahkan kegiatan agar tidak monoton dan para peserta tetap antusias mengikuti kegiatan pelatihan, tim juga menyiapkan sesi kuis berhadiah dalam bentuk tanya jawab secara online melalui aplikasi Kahoot. Kahoot merupakan aplikasi online yang dapat digunakan dengan mudah untuk membuat permainan edukasi melalui url: https://kahoot.com/. Aplikasi ini juga bisa menilai seberapa banyak pengetahuan yang dimiliki pengguna melalui skor yang diraih, sehingga menarik untuk diterapkan pula pada tahap evaluasi kegiatan PKM ini, selain melalui hasil kuisioner

2. Persiapan Kegiatan

Dalam penyelenggaraannya, kegiatan Pengabdian kepada Masyarakat ini 3 bulan sebelumnya telah melakukan berbagai persiapan terlebih dulu. Yaitu :

a) Melakukan survey pihak UMKM di daerah Tangerang Selatan, mengenai materi pelatihan apa yang diperlukan untuk mendukung usaha mereka, dan kemampuan dasar mereka telah sejauh apa dalam penggunaan aplikasi online

b) Menyiapkan surat kerjasama antara perwakilan UMKM di Tangerang Selatan, untuk melaksanakan kegiatan PKM

c) Menyiapkan modul pelatihan berupa Pembuatan Iklan Produk berbasis Animasi menggunakan Animatron.

d) Menyiapkan video iklan animasi yang telah dibuat melalui Animatron, untuk diputar dan ditunjukkan kepada para peserta guna memberikan gambaran tentang iklan produk berbasis animasi seperti apa yang akan mereka buat dalam pelatihan.

e) Menyiapkan sarana jaringan internet yang memadai, dikarenakan pelatihan yang sebelumnya direncanakan akan dilaksanakan langsung di lab, di rubah secara daring. Sehingga ketersediaan jaringan internet yang baik harus terpenuhi.

f) Melakukan latihan/gladi resik kegiatan PKM dan rapat rutin seluruh anggota PKM untuk melihat kesiapan acara

g) Menyiapkan brosur untuk memberikan informasi yang lebih informatif terhadap pelatihan yang akan dilaksanakan kepada peserta UMKM

h) Menyiapkan pertanyaan quiz berhadiah untuk peserta UMKM, dan cara bagaimana memberikan quiz tersebut agar lebih menarik

i) Menyiapkan link registrasi untuk pendaftaran peserta, yang dapat diakses melalui URL: http://bit.ly/workshop_animasi 
j) Menyiapkan link evaluasi untuk menjaring kesan dan saran dari para peserta saat nanti telah menyelesaikan kegiatan PKM, yang dapat diakses melalui URL: http://bit.ly/eval_pelatihan_animasi

\section{Pelaksanaan Kegiatan}

Pada pelaksanaannya, kegiatan pengabdian kepada masyarakat ini dimulai sesuai dengan jadwal yang telah direncanakan yaitu Sabtu, tanggal 3 April 2021 pada pukul 09:00 hingga 12:30 melalui sarana Google Meet dengan url berikut:

\begin{tabular}{|c|}
\hline $\begin{array}{c}\text { Join with Google Meet } \\
\text { meet.google.com/ihb-dgmq-ewf } \\
\text { Join by phone }\end{array}$ \\
(US) +1 929-220-3736 (PIN: 848776603) \\
\hline
\end{tabular}

Untuk kegiatan inti, tim mengalokasikan waktu kurang lebih 2 jam dalam menyampaikan kedua sesi materi. Berikut adalah detail acara kegiatannya:

Tabel 1. Rangkaian Acara PKM

\begin{tabular}{|c|l|l|}
\hline Waktu & \multicolumn{1}{|c|}{ Kegiatan } & \multicolumn{1}{|c|}{ Penanggungjawab } \\
\hline $08: 30-09: 00$ & Gladi bersih Tim & Tim \\
\hline $09: 00-09: 10$ & $\begin{array}{l}\text { Registrasi ulang peserta } \\
\text { (pengecekan daftar hadir) }\end{array}$ & Tim \\
\hline 09:10-09:20 & Pembukaan acara & $\begin{array}{l}\text { Ketua Tim \& Ketua } \\
\text { Program Studi }\end{array}$ \\
\hline 09:20-10:30 & $\begin{array}{l}\text { Sesi 1: Penjelasan Dasar } \\
\text { Animatron }\end{array}$ & Tim \\
\hline 10:30-11:50 & $\begin{array}{l}\text { Sesi 2: Studi kasus (praktek } \\
\text { pembuatan iklan dengan } \\
\text { Animatron) }\end{array}$ & Tim \\
\hline 11:50-12:00 & Tanya Jawab Peserta & Moderator \\
\hline 12:00-12:10 & Quiz/Game Kahoot & Moderator \\
\hline $12: 10-12: 20$ & Pengisian Kuisioner Evaluasi & Moderator \\
\hline $12: 20-12: 30$ & Penutupan & Ketua Tim \\
\hline & & \\
\hline
\end{tabular}

Dalam sesi acara yang pertama, penyampaian dasar menu-menu Animatron disampaikan oleh Tasya Aulia selaku perwakilan mahasiswa tim PKM, dengan menampilkan file PPT mulai dari pukul 09:20 hingga 10:30. Sedangkan untuk sesi yang kedua, penjelasan dilakukan secara langsung bersamaan dengan praktek pembuatan iklan oleh Muhammad Azamy selaku perwakilan mahasiswa dibantu oleh moderator dan anggota tim PKM lainnya. 

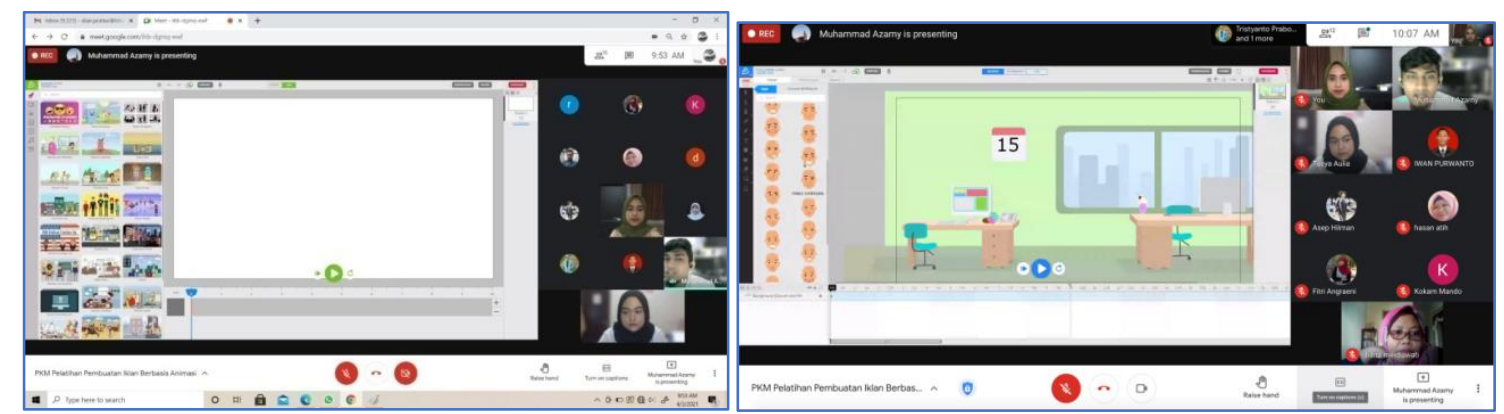

Gambar 3. Dokumentasi Kegiatan PKM Sesi I dan II

Setelah kedua acara inti selesai, kegiatan dilanjutkan dengan pembagian doorprize melalui acara quiz Kahoot. Dimana para peserta diminta untuk mengakses laman Kahoot dan menjawab 5 buah pertanyaan berbentuk pilihan ganda yang ada di dalamnya dengan waktu terbatas (1 menit). Bagi 3 peserta peraih poin terbanyak, akan diberikan hadiah setelah acara keseluruhan selesai. Berikut adalah foto dokumentasinya:

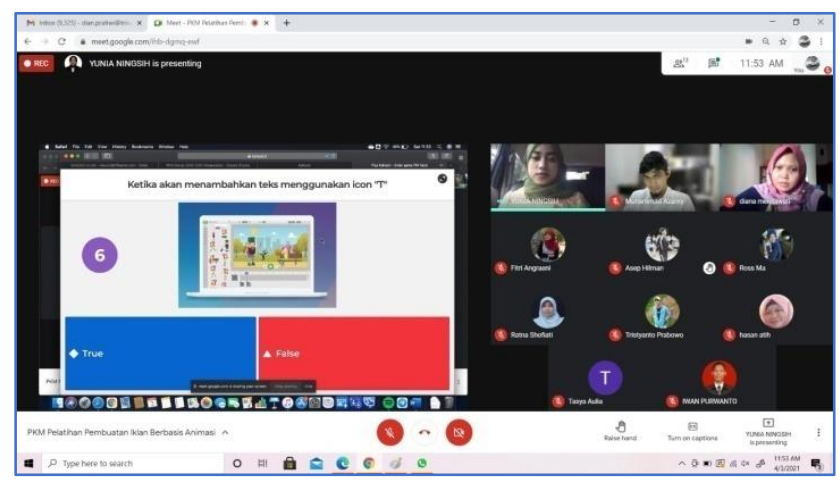

Gambar 4. Dokumentasi Kegiatan PKM Sesi Quiz

Sebelum dilakukan penutupan acara oleh ketua tim, peserta juga diminta untuk mengisi kuisioner evaluasi melalui Google Form (URL: http://bit.ly/eval_pelatihan_animasi) guna mendapatkan penilaian dari sisi materi, tim panitia, fasilitas, maupun kesiapan kegiatan PKM.

\section{Hasil dan Pembahasan}

Dari pelaksanaan kegiatan PKM ini, didapat bahwa kegiatan yang dilakukan secara daring memiliki hasil yang cukup berbeda dengan secara luring. Secara daring, hasil keberhasilan penyampaian materi kepada para peserta cukup sulit untuk diketahui, karena tim penyelenggara tidak dapat menerima masukan atau umpan balik secara langsung/tatap muka dengan para peserta sehingga sulit untuk melihat maupun mengetahui tingkat kesuksesannya. Untuk dapat mengukurnya, evaluasi kemudian dilakukan melalui serangkaian pertanyaan dalam Google Form, yang diberikan tepat setelah pelaksanaan materi sesi II selesai.Namun sayangnya, hanya 5 dari 6 peserta yang bersedia mengisi kuisioner evaluasi tersebut. Dan dari kelima peserta tersebut, nilai yang diberikan oleh peserta terhadap setiap pertanyaan mengenai jalannya kegiatan rata-rata diatas 4 dari skala 1-5, yang artinya mereka puas mengikutinya, 
bermanfaat bagi peserta, pengelolaan waktu pelatihan sudah baik, dan kejelasan maupun pengetahuan para instruktur sudah cukup mumpuni. Hal ini dapat dilihat melalui tabel 2 berikut ini:

Tabel 2.Rekap Nilai Kuisioner Evaluasi PKM dari Para Peserta

\begin{tabular}{|c|c|c|c|c|c|c|c|c|}
\hline \multirow[b]{2}{*}{ No } & \multirow{2}{*}{$\begin{array}{l}\text { Pertanyaan } \\
\text { Kuisioner }\end{array}$} & \multicolumn{7}{|c|}{ Penilaian $(1-5)$} \\
\hline & & $\begin{array}{c}\text { Peserta } \\
1\end{array}$ & $\begin{array}{c}\text { Peserta } \\
2\end{array}$ & $\begin{array}{c}\text { Peserta } \\
3\end{array}$ & $\begin{array}{c}\text { Peserta } \\
4\end{array}$ & $\begin{array}{c}\text { Peserta } \\
5\end{array}$ & $\begin{array}{c}\text { Peserta } \\
6\end{array}$ & $\begin{array}{l}\text { Rata- } \\
\text { rata }\end{array}$ \\
\hline 1 & $\begin{array}{l}\text { Pengetahuan umum } \\
\text { instruktur mengenai materi } \\
\text { pelatihan (Sesi 1) }\end{array}$ & 5 & 5 & 3 & 5 & 5 & - & 4.6 \\
\hline 2 & $\begin{array}{l}\text { Kejelasan instruktur dalam } \\
\text { penyampaian materi (Sesi } \\
\text { 1) }\end{array}$ & 5 & 4 & 3 & 5 & 5 & - & 4.4 \\
\hline 3 & $\begin{array}{l}\text { Cara penyampaian materi } \\
\text { (Sesi 1) }\end{array}$ & 5 & 5 & 3 & 5 & 5 & - & 4.6 \\
\hline 4 & $\begin{array}{ll}\text { Respon } & \text { terhadap } \\
\text { pertanyaan peserta (Sesi 1) }\end{array}$ & 5 & 5 & 4 & 5 & 5 & - & 4.8 \\
\hline 5 & $\begin{array}{l}\text { Pengelolaan waktu dalam } \\
\text { menyampaikan materi (Sesi } \\
\text { 1) }\end{array}$ & 4 & 5 & 3 & 5 & 4 & - & 4.2 \\
\hline 6 & $\begin{array}{l}\text { Kualitas materi pelatihan } \\
\text { (Sesi 1) }\end{array}$ & 5 & 5 & 4 & 5 & 4 & - & 4.6 \\
\hline 7 & $\begin{array}{l}\text { Manfaat yang didapat dari } \\
\text { pelatihan ini (Sesi 1) }\end{array}$ & 5 & 5 & 4 & 5 & 5 & - & 4.8 \\
\hline 8 & $\begin{array}{l}\text { Pengetahuan umum } \\
\text { instruktur mengenai materi } \\
\text { pelatihan (Sesi 2) }\end{array}$ & 4 & 5 & 4 & 5 & 5 & - & 4.6 \\
\hline 9 & $\begin{array}{l}\text { Kejelasan instruktur dalam } \\
\text { penyampaian materi (Sesi } \\
\text { 2) }\end{array}$ & 5 & 5 & 4 & 5 & 4 & - & 4.6 \\
\hline 10 & $\begin{array}{l}\text { Cara penyampaian materi } \\
\text { (Sesi 2) }\end{array}$ & 5 & 5 & 4 & 5 & 4 & - & 4.6 \\
\hline 11 & $\begin{array}{l}\text { Respon terhadap } \\
\text { pertanyaan peserta (Sesi 2) }\end{array}$ & 5 & 5 & 4 & 5 & 5 & - & 4.8 \\
\hline 12 & $\begin{array}{l}\text { Pengelolaan waktu dalam } \\
\text { menyampaikan materi (Sesi } \\
\text { 2) }\end{array}$ & 5 & 5 & 4 & 5 & 4 & - & 4.6 \\
\hline 13 & $\begin{array}{l}\text { Kualitas materi pelatihan } \\
\text { (Sesi 2) }\end{array}$ & 5 & 5 & 4 & 5 & 4 & - & 4.6 \\
\hline 14 & $\begin{array}{l}\text { Manfaat yang didapat dari } \\
\text { pelatihan ini (Sesi 2) }\end{array}$ & 5 & 5 & 4 & 5 & 5 & - & 4.8 \\
\hline 15 & $\begin{array}{l}\text { Kondisi infrastruktur Media } \\
\text { PKM Online }\end{array}$ & 5 & 5 & 4 & 5 & 5 & - & 4.8 \\
\hline 16 & $\begin{array}{l}\text { Fasilitas yang saya terima, } \\
\text { Paket Internet, Modul, E- } \\
\text { Certificate }\end{array}$ & 5 & 5 & 4 & 5 & 5 & - & 4.8 \\
\hline & Rata-rata & 4.875 & 4.9375 & 3.75 & 5 & 4.625 & & 4.63 \\
\hline
\end{tabular}




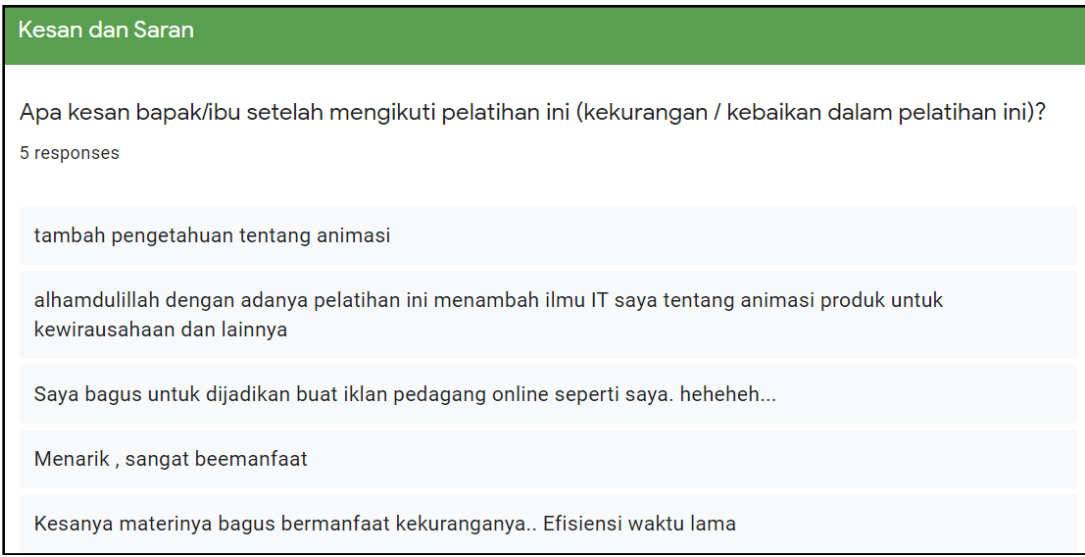

Gambar 5. Kesan dan Saran Peserta terhadap Pelatihan

Apa saran bapak/ibu untuk pelatihan berikutnya?
5 responses
sering - sering membuat pelatihan semacam ini karena sangat membantu kami
untuk kedepan iusahakan peserta diberikan kesempatan mempraktekan dan hasilnya diberikan koreksian jika
ada kekurangannya
Kalau bisa lebih detail lagi soal penjelasan pemasaran produk menggunakan animasi
Di jadwalkan sesi berikutnya
Iklan animasi yang simple untuk promo produk

Gambar 6. Saran Peserta Kegiatan PKM

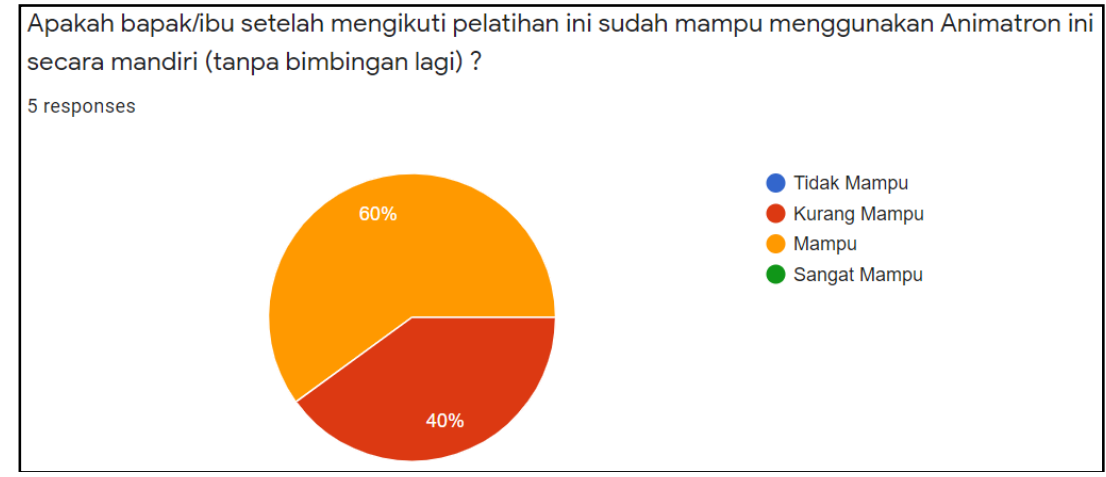

Gambar 7. Grafik Penilaian Kemandirian Peserta dalam Menggunakan Animatron

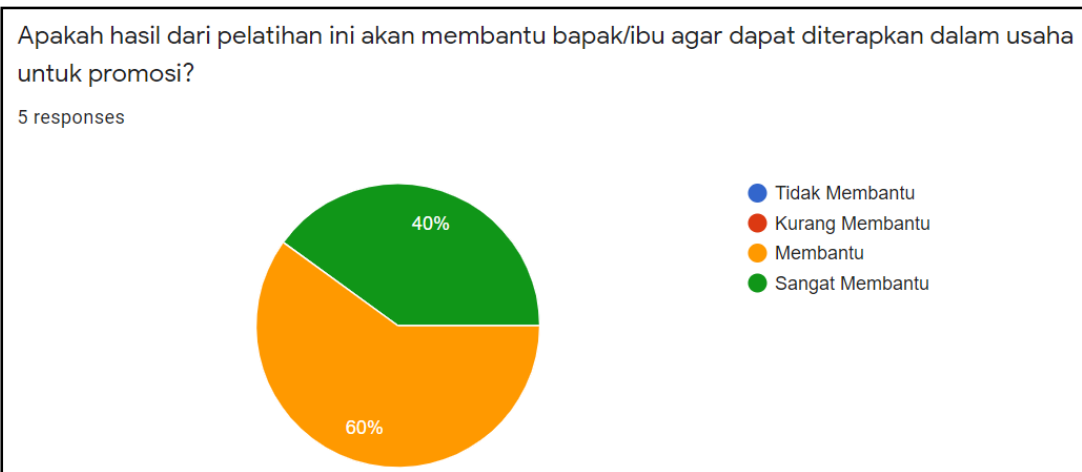

Gambar 8. Grafik Penilaian Peserta terhadap Efektifitas Pelatihan pada Usaha/Promosi 
Selain itu, tanggapan, saran maupun kritikan juga dapat diberikan oleh para peserta melalui Grup WhatsApp yang dibentuk sejak pendaftaran PKM. Berikut adalah sebagian hasil tanggapannya:

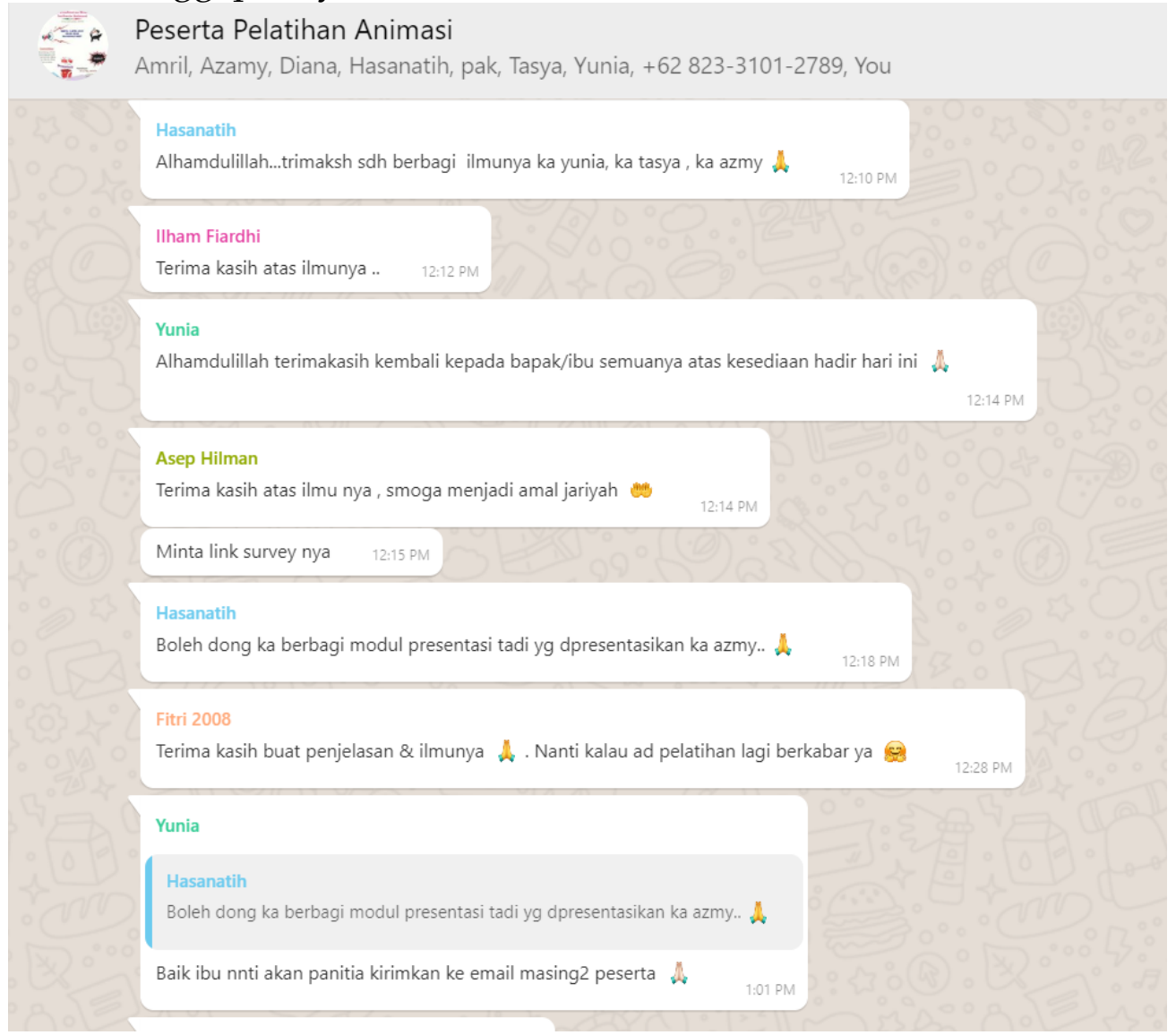

Gambar 9. Tanggapan Peserta terhadap Kegiatan PKM melalui Grup WhatsApp

Mengenai materi Animatron yang secara keseluruhan dari peserta belum pernah mengetahui dan memakainya untuk membuat iklan animasi, dari hasil pelatihan ini didapati bahwa 3 dari 5 peserta yang mengisi kuisioner telah menyatakan mampu untuk menggunakan Animatron secara mandiri tanpa bimbingan lagi (Gambar 6). Sedangkan 2 peserta lainnya, menyatakan belum mampu dan masih perlu dibimbing kembali jika pelatihan berikutnya dilaksanakan lagi nantinya. Hal ini bisa dikarenakan tools Animatron masih belum banyak dikenal oleh masyarakat, dan mayoritas mereka hanya pernah menggunakan media sosial Instagram dan Facebook untuk membuat iklan. Sehingga tidak mudah bagi mereka untuk mempelajari teknologi baru, yang lebih kompleks dengan hanya satu kali pertemuan. Namun keseluruhan dari para peserta, yang dapat dilihat pada Gambar 7, menyatakan pula bahwa pelatihan pembuatan Animasi yang mereka terima tersebut akan dapat membantu dalam mempromosikan usaha mereka.

Selain dengan menggunakan kuisioner, panitia juga memberikan quiz berhadiah melalui sarana Kahoot untuk menilai seberapa banyak pengetahuan para peserta yang telah didapat dari kegiatan PKM tersebut mengenai pembuatan animasi. Quiz yang berisi 5 buah pertanyaan tersebut diikuti oleh 6 peserta, dimana 4 darinya 
berhasil mendapatkan poin yang tinggi. Dengan demikian, dapat disimpulkan bahwa materi yang disampaikan instruktur berhasil diterima dan dipahami dengan cukup baik oleh sebagian besar peserta. Hal ini juga bisa terlihat pada respon positif yang dikirim peserta melalui grup whatsApp PKM (pada Gambar 8), dimana ada beberapa peserta yang berkeinginan untuk mengikuti pelatihan lagi jika diadakan kembali nantinya, Dengan demikian, dapat disimpulkan bahwa kegiatan pelatihan pembuatan iklan animasi ini berhasil dijalankan dengan baik dan telah memberikan dampak positif bagi para peserta yang mengikutinya.

\section{Simpulan dan Rekomendasi}

Kesimpulan yang didapat dari kegiatan Pelatihan Pembuatan Iklan Produk berbasis Animasi ini diantaranya:

a. Dari 16 peserta yang telah mendaftar, hanya 6 peserta saja yang mengikuti kegiatan secara purna waktu. Meskipun demikian, dari seluruh peserta yang hadir, sebagian besar dari mereka telah memahami materi yang disampaikan dengan baik. Hal ini terlihat dari hasil quiz berhadiah Kahoot, dimana 4 dari 6 peserta berhasil mendapatkan banyak poin dari setiap pertanyaan seputar materi pelatihan yang benar terjawab.

b. Berdasarkan hasil kuisioner awal pendaftaran (http://bit.ly/workshop_animasi), penggunaan Animatron sebagai media untuk membuat iklan animasi produk UMKM belum pernah diterapkan sebelumnya oleh seluruh peserta, dan mayoritas peserta hanya menggunakan media sosial untuk melakukan promosi atau beriklan produk mereka. Sehingga pemilihan Animatron sebagai media pembuatan iklan animasi pada kegiatan ini sangat tepat dilakukan, guna memberikan pengetahuan dan keterampilan para peserta UMKM dalam membuat iklan yang lebih menarik lagi.

c. Berdasarkan hasil kuisioner evaluasi (http://bit.ly/eval_pelatihan_animasi), sebanyak $60 \%$ peserta menyatakan mampu menerapkan Animatron secara mandiri dan pelatihan ini $100 \%$ peserta menyatakan akan membantu dalam mempromosikan usaha mereka nantinya. Sehingga dapat disimpulkan bahwa pelatihan ini telah berhasil memberikan pengetahuan serta keterampilan para pelaku UMKM untuk membuat iklan produk dengan mudah dan lebih menarik dalam bentuk animasi

Sedangkan untuk saran atau rekomendasi yang dapat diberikan dari hasil kegiatan ini yaitu:

a) Perlu adanya penambahan sesi pelatihan, guna memberikan pemahaman yang lebih baik lagi tentang materi Animatron kepada para peserta

b) Pelatihan sebaiknya dilakukan oleh peserta dengan mempraktekkan langkahlangkah yang diberikan instruktur secara langsung menggunakan komputer masing-masing, guna memberikan hasil bentuk iklan yang konkrit.

\section{Daftar Pustaka}

Afgan, Q. (2012). Pembuatan Animasi 3D Sebagai Iklan Layanan Masyarakat Pentingnya Sosialisasi Penghijauan pada Walhi Yogyakarta. Repository Amikom. 
http://repository.amikom.ac.id/files/Naskah_Publikasi 08.11.2557.pdf

Cook, M. (2019). Animation and Advertising. Palgrave Animation, Springer Nature Switzerland AG Publisher.

Hadi, S. (2015). Pelatihan Animasi Guna Mendorong Industri Animasi Iklan. Tribun News. https://surabaya.tribunnews.com/2015/08/18/pelatihan-animasi-gunamendorong-industri-animasi-iklan

Hasibuan, L. (2020). Putri Tanjung Beberkan Dampak Pandemi terhadap UMKM RI. CNBC Indonesia. https://www.cnbcindonesia.com/entrepreneur/20201126200053-25205012/ putri-tanjung-beberkan-dampak-pandemi-terhadap-umkm-ri

Indrawan, G., Aryanto, K. Y. E., \& Sariyasa. (2017). Pelatihan dan Pendampingan Animasi 2D sebagai Media Pembelajaran di SMKN 1 Sawan. Seminar Nasional Pengabdian Kepada Masyarakat (SENADIMAS), 217-223.

Melet, A. (2011). Animatron Reviews \& Product Details. Animatron. https://www.g2.com/products/animatron/reviews

Narayanan, A. N. (2019). Animatron Reviews. https://www.capterra.com/p/155780/Animatron/reviews/

Permana, A. A. J., Saputra, P. H., \& Dantes, G. R. (2017). Pelatihan Animasi 3 Dimensi (3D) dan Pemrograman Scratch untuk Siswa Sekolah. Seminar Nasional Vokasi Dan Teknologi (SEMNASVOKTEK), 112-119.

Pratiwi, D., Zuhdi, A., Shofiati, R., \& Pratama, R. R. (2021). Penerapan Animaker dalam Pembuatan Iklan Produk UMKM berbasis Animasi. Jurnal Pengabdian Kepada Masyarakat (ABDIMAS BSI), 1(1), 138-147.

Wiyaka, Lestari, S., \& Nur'Aini, S. (2017). Pelatihan Pembuatan Animasi untuk Pembelajaran Bahasa Inggris Bagi Guru Sekolah Dasar Kota Semarang. https://media.neliti.com/media/publications/168719-ID-pelatihan-pembuatananimasi-untuk-pembel.pdf

Zebua, T., Nadaek, B., \& Sinaga, S. B. (2020). Pengenalan Dasar Aplikasi Blender 3D dalam Pembuatan Animasi 3D. Jurnal ABDIMAS Budi Darma, 1(1), 18-21. 